\title{
2. OBJECTIVES OF DRILLING ON YOUNG PASSIVE CONTINENTAL MARGINS: APPLICATION TO THE GULF OF CALIFORNIA ${ }^{1}$
}

\author{
David G. Moore and Joseph R. Curray, Scripps Institution of Oceanography, La Jolla, California
}

\section{INTRODUCTION}

The origin and evolution of passive continental margins are of great scientific interest and economic importance. When the JOIDES/Deep Sea Drilling Project was continued as IPOD (International Phase of Ocean Drilling), the scientific objectives of the drilling were directed toward three principal problems: continental margins, the ocean crust, and the ocean paleoenvironment. Two separate advisory panels were appointed to deal with the problems of continental margins, because in terms of plate tectonics continental margins may be either "passive," lying in an intraplate position, or "active," lying at a plate edge with active seismicity and sometimes volcanism. Leg 64 was devoted to drilling objectives outlined mainly by the Passive Continental Margin Advisory Panel. This chapter briefly outlines some of the objectives considered by that panel, as applied to drilling a young margin like the Gulf of California.

Today, approximately half of the world's continental margins are passive and half are active. This proportion has, however, changed through geological time. During the Triassic, about $200 \mathrm{Ma}$, most of the continental mass of the world was assembled into one supercontinent, Pangea, and virtually all of its margins were of the active or subduction type. Earlier, during Paleozoic time, the proportion of active to passive margins may have also been more nearly equal for some periods of time. The origin and evolution of these margins are important, because they may have been the sites of deposition of the bulk of the sedimentary rock accumulations of the world. It has been estimated that perhaps $60 \%$ of all the world's sediments younger than 200 m.y. are contained in continental margins, most of them of the passive type. Even after these sedimentary accumulations are subjected to the orogeny of converting passive to active margins or of continent-continent collision, these huge reservoirs of sediment represent permanent monuments which form the bulk of the mountain ranges of the world.

The events and the rocks formed during the early evolution of passive margins are important because they represent the birth of oceans. It is during this period that there occurs the interaction among old continental rocks, new, hot oceanic rocks, and encroaching waters of the oceans that may be one of the most important processes in the accumulation of mineral deposits. Simi-

\footnotetext{
${ }^{1}$ Curray, J. R., Moore, D. G., et al., Init, Repts. DSDP, 64: Washington (U.S. Govt. Printing Office).
}

larly, sedimentation in the juvenile ocean basins commonly produces a combination of evaporites, source beds, and reservoir rocks that constitutes a favorable environment for hydrocarbon accumulation. As important as they are, however, the records of these early events and the nature of the rocks formed are most difficult to decipher from study of older or mature passive continental margins. These early events and clues are deeply buried by sediment and blurred by time. In theory, then, they can be more easily interpreted from geophysical study and drilling of a young passive margin. Even here, however, the record is complex and not necessarily directly applicable to a general understanding of the problems. All continental margins are different; as a corollary, not all young passive continental margins and ocean basins will necessarily evolve into mature margins and ocean basins.

We will first examine some of the objectives for study and drilling on passive continental margins and, second, attempt to determine which of these may be applicable to solving general problems with a drilling program in the Gulf of California. Parts of this chapter are condensed from the IPOD Passive Continental Margin Advisory Panel's “white paper," (Curray, 1980).

\section{FORMATION AND EVOLUTION OF PASSIVE MARGINS}

Many models have been proposed for the formation of passive continental margins, but in recent years most of them have involved rifting and sea-floor spreading. We have adopted such a model, shown in an extremely simplified form in Figure 1, based on general characteristics now observed by modern seismic surveying and deep drilling. Conceptually, the evolution includes the following phases: (1) doming, (2) rifting, (3) onset of drifting or sea-floor spreading, and (4) subsequent postrift evolution. This model follows similar models published by Dewey and Bird (1970), Falvey (1974), and others.

\section{Prerift Doming}

Rifting is sometimes preceded or accompanied by a period of uplift or doming, often contemporaneous with volcanism. It has been presumed that the doming is caused by thermal expansion and/or phase change. Erosion of the uplifted region may then thin the crust, resulting in further isostatic uplift, while thermal metamorphism of the lower continental crust may cause additional thinning. The modern examples which have led to this part of the concept are regions of uplift sur- 


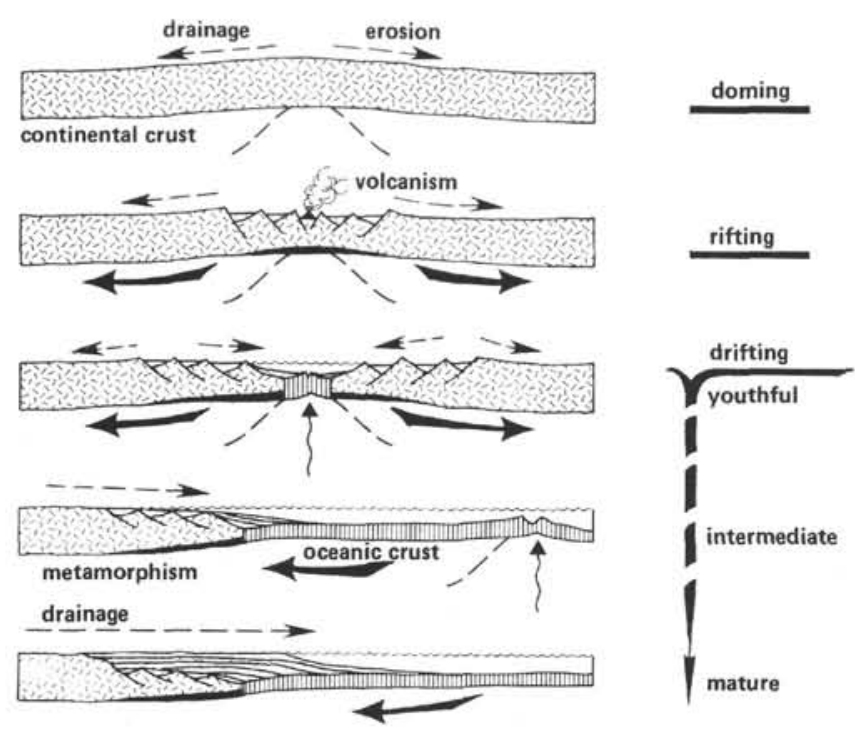

Figure 1. Model of formation and evolution of rift segments of passive continental margins, as adapted from many published sources. Adapted from Curray (1980).

rounding the East African Rift Valleys and the Red Sea. Recent studies suggest, however, that doming may not be a general characteristic of rifted margins.

\section{Rifting}

Evidence of the nature of rifting as constituting the initial stage of margin development depends heavily on the East African and other rift systems, because prerift and synrift sediments have been sampled in only a few places in the ocean basins. Rifting may follow a subparallel pattern, as exemplified by the Viking Graben of the North Sea and the continental margin of North Biscay, or a trilete pattern, that is, ridge-ridge-ridge triple junction, as exemplified by such segments of Atlantic margin as West Equatorial Africa and the Benue Trough. Commonly, one of the arms of the trilete pattern fails, leaving an aulacogen trending inland from the approximate $120^{\circ}$ angle in the continental margin.

During this rifting stage, the basic structural framework of the margin is determined by the pattern of rifting and preexisting zones of structural weakness, which may show evidence of palimpsest structural control. Within the rift, basic and alkaline intrusive rocks may be intercalated with and thickly covered by contemporaneous, coarse, clastic, continental sediments. Depending on the altitude of the rift valley and climate, repeated transgressions and regressions may result in evaporite deposition on the extending continental crust and on some of the oceanic crust formed early in the next stage. During this rifting stage, if uplift or doming preceded rifting, drainage is directed away from the rift valley, thus restricting the clastic sediment supply. If doming did not precede or accompany the rifting, or if access to an abundant terrestrial sediment supply is provided at one end of the rift or by the drainage gap, the rift, and sometimes the early stages of formation of the resulting, elongate, young ocean basin, may be filled with terrigenous sediments as rapidly as opening occurs.
Examples are the northern ends of the Gulf of California and the Andaman Sea (Fig. 2). Finally, if no prerift uplift occurs, the rifting process may be submarine in an older epicontinental sea, and accompanying volcanism may not be widespread.

Observations of the normal faults formed during the rifting stage indicate that they may be either horst-andgraben faults, or faults of the listric type, steep-dipping at the surface and soling out into deep crustal discontinuities. The mechanism of development of such faults is surficial stretching and propagation of the faults downward.

\section{Drifting, or the Onset of Sea-Floor Spreading}

After rifting, and with the onset of sea-floor spreading, oceanic crust begins to accrete at the edges of the separating blocks of attenuated continental lithosphere. The nature of the change from rifting to drifting and the geology of the continent/ocean boundary zone formed at this time are not fully understood. Overlaps and underlaps between reconstructed continents suggest variations in the width of the continent/ocean boundary zone that may reflect differing extensions of continental crust in the rifting stage, pervasive jointing and injection of dikes into the crust, and local variations in geology. In other areas, however, oceanic magnetic anomalies and a characteristic isostatic gravity anomaly suggest that the continent/ocean boundary may be a narrow zone, linear over hundreds of kilometers. Important factors that may influence the geology of the boundary may be the altitude of the continent at this time, and whether rifting starts in a region of thermal uplift or in an epicontinental sea.

The change from rifting to sea-floor spreading marks a major change in the thermal regime of the margin. During rifting, the heat source remains fixed beneath the rift axis, but when sea-floor spreading begins this source moves away from the continent/ocean bound-

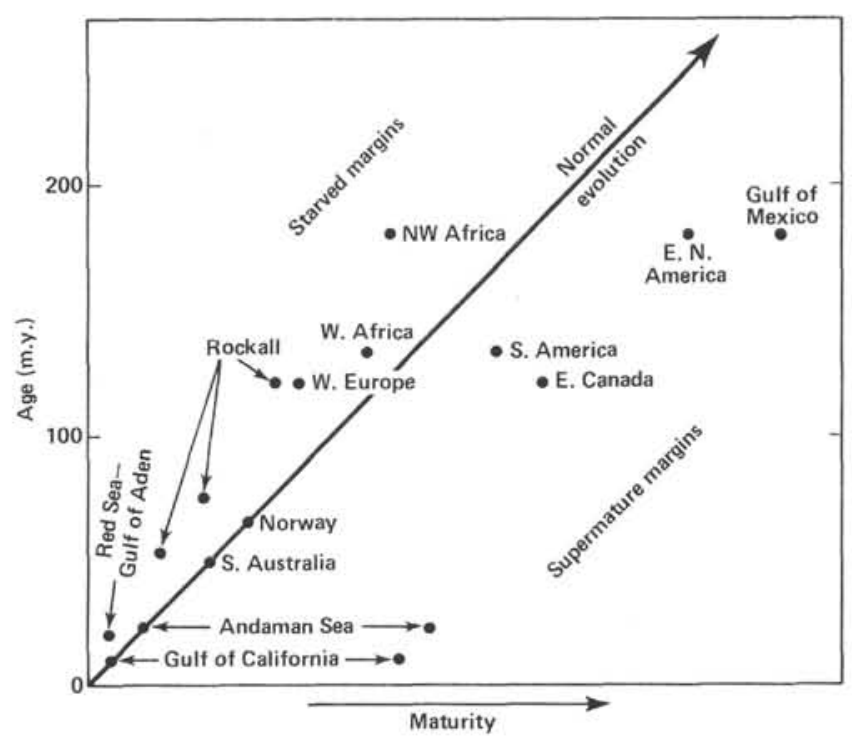

Figure 2. Relationship between age and maturity of passive continental margins. 
ary, allowing the new margin to cool. It has been suggested that secondary heating and thermal expansion at the onset of spreading may produce a second short period of uplift and a "break-up unconformity" (Falvey, 1974).

Another important variable that may influence the transition from unaltered continental crust to simple oceanic crust showing linear magnetic anomalies is the nature of the early spreading. Whereas along some continental margins, identifiable, correlatable magnetic anomalies lie immediately adjacent to the toe of continental crust, an intermediate, magnetic quiet zone or a zone with unidentifiable and uncorrelatable magnetic anomalies may lie between the continental crust and the simple oceanic crust. The nature of the magnetic quiet zone is d.batable and may vary from one margin to another, but some magnetic quiet zones may have been formed by a process of "diffuse extension." Cochran (1981) suggests that this process is responsible for what previous investigators had considered to be a first phase of opening of the Gulf of Aden and the Red Sea. Spreading may have taken place over an area as much as 100 $\mathrm{km}$ wide in a rift valley environment without an organized spreading center, before it concentrated along a single spreading axis. We now believe (Moore and Curray, this volume, Pt. 2; Curray et al., this volume, Pt. 2) that diffuse extension makes possible different crustal origins and composition, from continued extension and volcanic injection of crust which was originally continental to a purely oceanic crust that was formed without a single axis of spreading and locus of injection of basaltic magma.

The subsidence curves derived from various margins are similar to each other and to empirical cooling curves constructed for the oceanic crust, indicating that the nature of the subsidence is apparently largely independent of both the structure and initial altitude of the continent. Rates and amounts of subsidence apparently depend upon isostatic considerations such as crustal thickness and density and sediment and water loading (Watts and Steckler, 1979). One effect of the subsidence is to allow wide transgression of the margin, often revealed as an important unconformity with onlap separating the faulted synrift section from the unfaulted postrift section. Another important effect of subsidence is to tilt the margin gently toward the ocean, reversing the drainage pattern. During the early spreading stage, fracture zones and aseismic ridges in the young ocean may strongly influence continental margin structure and sedimentation, locally prolonging restricted evaporite or anoxic environments before open oceanic circulation is established. These ridges may locally segment the passive margins and the young ocean into independent structural basins separated along strike.

\section{Postrift Evolution}

The subsequent evolution of the margin is a function both of age and of the poorly understood interplay between regional and local differential subsidence, sedimentation, eustatic sea level fluctuations, climate, and ocean circulation. Two end-members of rifted margins appear to exist: starved and supermature margins (Fig. 2 ). With the onset of drifting, exponential thermal subsidence starts, as well as that resulting from sedimentand water-loading. The starved margins are characterized by a thin, prograding sedimentary cover and may be chronologically old or young. Examples include the Northeast Atlantic Ocean. Only starved margins have been drilled during IPOD, owing to the limited drilling capability of Glomar Challenger (Sibuet, Ryan, et al., 1979; Montadert, Roberts, et al., 1979). Supermature margins are characterized by prograding wedges of sediments, $10 \mathrm{~km}$ or more in thickness, which deeply bury the faulted and subsided continental edges. These are exemplified by the eastern margin of North America. A full study of mature margins will be possible only with increased drilling capacity.

\section{IMPORTANT GEOLOGICAL AND GEOPHYSICAL PROBLEMS RELATED TO YOUNG PASSIVE MARGINS}

\section{Structural Evolution}

\section{Ocean/Continental Crustal Boundary}

Precise delineation and description of the boundary between continental and oceanic crust are important objectives for drilling, inasmuch as interpretations from geophysical methods alone remain controversial. The nature of this boundary may manifest itself in different ways in different places, but it should be studied first in youthful or starved margins where it is now feasible to calibrate and confirm geophysics by drilling. The boundary along transform fault segments of passive margins probably differs from the more common rift segments and should also be tested in young margins.

\section{Attenuation of the Crust and/or Lithosphere}

Geophysical data suggest that parts of many passive margins are underlain by an attenuated continental crust. Attenuation may occur early in the development of the margin, or it may occur later, during stages of rapid subsidence. Different styles of attenuation may depend on initial tectonic setting and mode of opening, and differing mechanisms have been proposed, including extension by horst and graben faulting or rotational block faulting along listric normal faults. One distinct type of margin that may be governed by more than one mechanism is the kind dominated by transform faulting and oblique opening, such as the Gulf of California. Other models are proposed, but only geophysical studies combined with drilling into the crust underlying continental margins will allow more precise delineation of the mechanisms at work.

\section{Subsidence}

Massive subsidence follows the rifting phase of passive margins. Although a substantial amount of subsidence is due to sediment-loading, the subsidence of sediment-starved continental margins indicates that sedi- 
ment-loading is not the only factor to be considered. Preliminary studies suggest that the outer parts of passive margins subside at almost the same rates, or at least along the same types of exponential curves as aging oceanic crust, starting from the time spreading begins. Worldwide changes in relative subsidence rates may be related to tectonic and/or eustatic cycles, and local and regional changes are related to sediment-loading. Accurate age-depth measurements obtained by drilling allow us to evaluate these fascinating possibilities.

\section{Gravity Sliding}

Mass movements are known to be common phenomena of continental margins. Stability of any sedimentary accumulation on a continental slope is, in simplest terms, a function of slope gradient, sediment type, rate of accumulation, and tectonic or oceanographic disturbances. Previous JOIDES and IPOD drilling, other marine geologic survey work, and surface mapping of ancient equivalents have shown that displaced sediments are common in outer continental margin deposits. As a byproduct of drilling toward other major targets, information on disturbed, slumped sequences is most helpful in the interpretation of seismic reflection lines.

\section{Transform Fault Segments}

Passive margins are complex mixtures of rift and transform segments. The structure and evolution of the transform segments are quite different from the rifted segments. Although some descriptions of these segments have resulted from preliminary exploration, we do not yet have sufficient information to understand them, especially their subsidence histories.

Detailed studies of two young ocean basins, the Gulf of California (Sharman, 1976) and the Andaman Sea (Curray et al., 1979), and studies on wax models (Oldenberg and Brune, 1975) have suggested an evolutionary sequence from initial rifts to mature rift-transform patterns. Initial rifts are irregular and are probably controlled in part by pre-existing lines of structural weakness. These irregular rifts evolve, early in the stage of drifting and sea-floor spreading, into rectilinear patterns of short segments of spreading rifts and transform faults. As spreading continues, the pattern tends to simplify itself, and new rift segments form in line with adjacent rifts to make fewer and longer segments of both rifts and transforms. We do not understand the relationship between this rift-transform pattern of evolution and the diffuse early spreading stage which has been postulated for the Gulf of Aden by Cochran (1981) and which we believe may have occurred in the Gulf of California.

\section{Sedimentary Evolution}

Sediments on passive continental margins monitor and record oceanic surface-water circulation, the vertical stratification and characteristics of the oceanic water column, eustatic sea level changes, and the paleoenvironment of the continental hinterland and of the juvenile rift.

\section{Oldest Sediments on Oceanic Crust}

These sediments date the onset of drifting and seafloor spreading. The facies reveal the environmental conditions at the time, including the depth of water and the circulation characteristics or degree of restriction of the incipient ocean basin.

Juvenile passive continental margins commonly preserve a sedimentary record of the early, restricted, marine paleoenvironments of the small ocean basins they surround. Anaerobic sediments with similar characteristics can also be preserved in an oceanic mid-water oxygen minimum. The distribution pattern of these anoxic sediments, which preserve an unusually high concentration of organic carbon along passive continental margins, is virtually unknown.

\section{Normal Continental Margin Facies Compared with the Anomalous Quaternary Record}

The two major aspects of the problem of facies distribution are:

1) What is the distribution of the anomalous Quaternary facies, and what changes did Quaternary conditions cause in depositional environments in the oceans -changes which have misled us in our attempts to understand Holocene or postglacial processes? How can these changes help us to understand other eustatic or tectonic changes of sea level, transgressions, and regressions?

2) What are the "normal," nonglacial processes of distribution and deposition of sediments, and at what age horizons can we find such "normal" sequences?

\section{Displaced Sediments; Gravity Slides}

Gravity sliding, already discussed briefly as one mechanism of deformation of the internal structure of passive margins, takes on an even greater significance in our attempts to understand and read the record of sedimentary sequences. Mass movements of sediments take all forms, from transport of sediment down canyons and fan valleys by turbidity currents to catastrophic slides, which displace large volumes of sediments from shallow-water to deeper-water environments. How can we recognize such movements in cores from the oceans or outcrops of ancient sediments?

\section{Diagenesis of Sediments}

The first early diagenesis of sediments occurs in the top few meters below the ocean floor, and the processes within this benthic boundary layer are the subject of intensive studies by biologists, sedimentologists, chemists, and physicists. Following this early diagenesis, lithification proceeds with the expulsion of interstitial waters, expulsion of water associated with the collapse of clay minerals, and reduction of porosity and permeability. Fluids are thereby redistributed into porous layers alternating with nonporous layers, leading to chemical reactions between the pore fluids and the host rocks. In this context, the thermal history of these sediments in a young ocean basin is of great importance. 
Diagenetic studies can be undertaken only if the holes are cored more or less continuously, and all logs relevant for a petrophysical evaluation are run. Extensive sampling of subsurface fluids is also a matter of prime importance.

The diagenesis of organic matter with depth is important in understanding the cycle of carbon among lithosphere, biosphere, and atmosphere and in following processes such as the origin and maturation of petroleum. Most of the world's organic carbon is in sedimentary rocks. Possible half of these sediments are on the continental rise, and yet little is known about their organic character. What is the source of organic matter? How much is there, and how well is it preserved? How is it altered biologically and thermally with depth? Is there enough of the right kind of organic matter to form petroleum? The diagenesis of organic material in the spreading axis environment of a young ocean basin, with its high heat flow, represents an important endmember in the maturation of hydrocarbons in very young sediments.

\section{Paleoclimatology and Paleoceanography}

The quantitative and qualitative composition of particulate or dissolved terrigenous input to continental margins is controlled by the geology of the continental hinterland, by the climatic processes above it, and by the size of the drainage basins which supply the terrigenous material to the continental edge. Owing to their higher sedimentation rates, continental margins also provide possibilities for understanding the development of the pelagic paleoenvironment that are not obtainable in the central parts of the oceans themselves.

Transects of drill sites across passive continental margins also provide insight into the vertical structure of the oceanic water column through time, because it is there that the intermediate and deep oceanic water masses impinge upon the rise and slope of the continents.

\section{THE GULF OF CALIFORNIA AS AN OBJECTIVE OF YOUNG MARGIN DRILLING}

\section{Background}

The Gulf of California has been an objective of deepsea drilling proposals for many years, because it represents one of the few examples in the modern world of a young, rifted ocean basin. As early as the October 1974 organizational meeting of the IPOD panels, recommendations were made to the Planning Committee for drilling in and around the Gulf. These recommendations originated largely with the Passive Margin Panel and the Ocean Crust Panel, but the other topical panels contributed to and supported them.

In 1976, the IPOD/JOIDES Planning Committee was asked to appoint a working group for the Gulf of California. Officially appointed in 1977, this group included, when final proposals were prepared, the following members: Dr. Agustín Ayala-Castañares, UNAM; Dr. James C. Ingle, Stanford University; Dr. Roger L. Larson, Lamont-Doherty Geological Observatory; Dr. Brian T. R. Lewis, University of Washington; Dr. David
G. Moore, Scripps; and Dr. Joseph R. Curray, Scripps, Working Group Chairman.

Many previous geological and geophysical expeditions had worked in the Gulf. A first IPOD Site Survey Cruise was conducted by Brian Lewis, University of Washington, in 1975 (Lewis et al., 1975); Scripps and Mexican scientists jointly conducted a Site Survey Cruise in 1978 with the Scripps ship Thomas Washington (Moore et al., 1978). A final drilling proposal was submitted in 1978, reviewed and approved by the JOIDES and DSDP Safety Panels, together with representatives of PEMEX and Consejo Recursos Minerales, and was recommended within Mexico by Dr. Agustín Ayala-Castañares, UNAM, and Dr. Edmundo Flores, CONYCYT.

\section{Outline of Tectonics and Geological History}

The concept that the Gulf of California originated by the separation of Baja California from mainland Mexico can be traced in the geological literature at least back to Wegener (1924). The general configuration of the shorelines, continental margins, and geology appear to match across the Gulf; the axis of the Gulf is seismically active; and the northern end of the Gulf is obviously related to the San Andreas Fault system of California.

With the advent of the modern concepts of sea-floor spreading, transform faults, and plate tectonics, and with improved knowledge of the geology, bathymetry, structure, and seismicity in and around the Gulf, further details can be explained. A plate tectonic model of the Gulf is today commonly accepted (Fig. 3). Various parts of this model can be attributed to many contributors, including Shepard (1950), Menard (1960), Hamilton

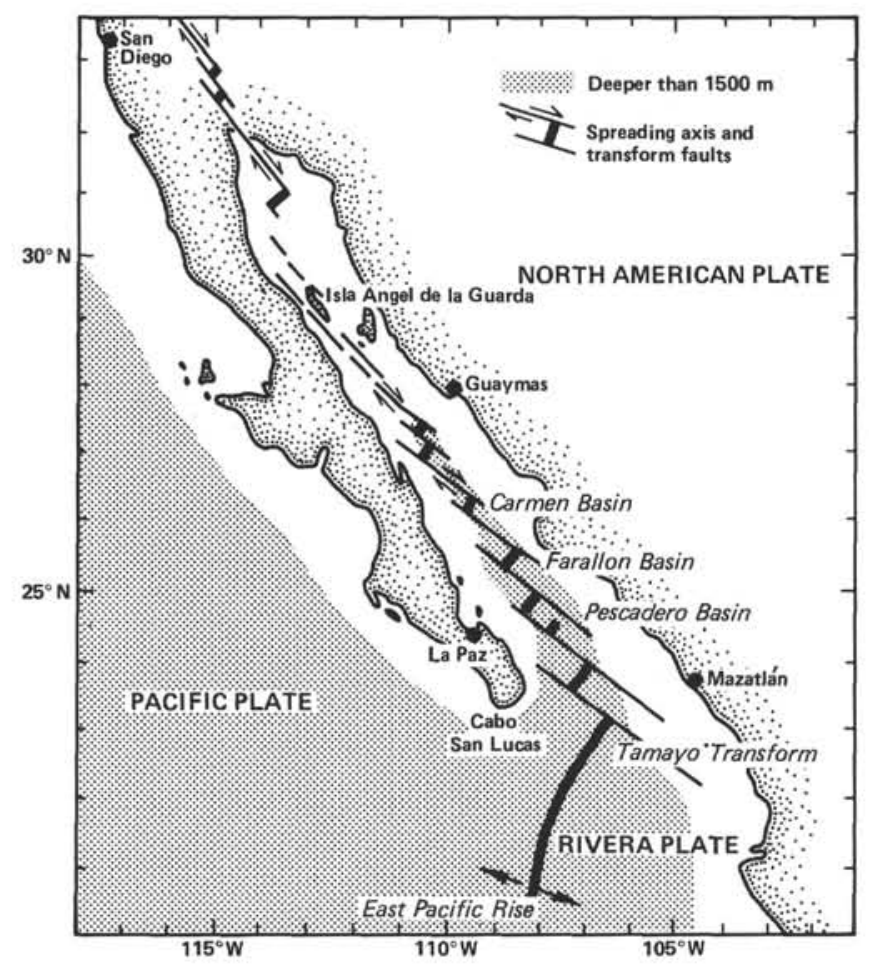

Figure 3. Simplified tectonic features of the Gulf of California. 
(1961), Kovach et al. (1962), Rusnak and Fisher (1964), Rusnak et al. (1964), Wilson (1965), Vine (1966), McKenzie and Parker (1967), Morgan (1968), Normark and Curray (1968), Moore and Buffington (1968), Larson et al. (1968), Sykes (1968), Gastil et al. (1968), Atwater (1970), Chase et al. (1970), Larson (1972), Karig and Jensky (1972), Moore (1973), Jensky (1974), Sharman (1976), and many others.

The East Pacific Rise enters the mouth of the Gulf (Fig. 3) and passes into a rectilinear system of short segments of spreading axes offset by transform faults; at the northern end, this motion is passed northward into the San Andreas Fault system. The complex system of spreading axes and transform faults is the boundary between the North American and Pacific lithospheric plates in the Gulf and between the Pacific and Rivera plates at the mouth of the Gulf. It is prominently displayed in the bathymetry and closely matches precisely positioned earthquake epicenter and microseism swarms (Reichle et al., 1976; Reichle and Reid, 1977). Some of the spreading axes have been further confirmed by very high heat-flow values (Lawver and Williams, 1979; Williams et al., 1979). Observations of hydrothermal deposits on small normal faults in the north Guaymas Basin (Lonsdale and Lawver, 1980) and seismic reflection records show thinning, faulting, and deformation of the sediments (Moore, 1973; Sharman, 1976).

In the light of newer observations of the sea floor, several generations of geological observations in California, Baja California, and mainland Mexico have in recent years been reinterpreted into an integrated geological history. Although not all scientists working on the problem agree in detail, many accept the following scenario (see, for example, Atwater, 1970). Before about $29 \mathrm{Ma}$, the Farallon Plate lay offshore from California and Baja California, and a subduction zone lay off the continental margin. When the first corner of the spreading axis and transform plate boundary between the $\mathrm{Pa}$ cific Plate on the west and the Farallon Plate contacted the subduction margin between the Farallon and North American plates, two triple junctions formed. These triple junctions migrated north and south, respectively, along the continental margin, and the plate boundary between the Pacific and North American plates became a right-lateral transform fault ancestral to the present San Andreas Fault. The northern triple junction is today at Cape Mendocino, California; the southern one was responsible for forming the Gulf of California. As the southern triple junction migrated southward, and as the transform fault system moved progressively inland into central California and accompanying right-slip faulting developed the Southern California Borderland, the triple junction, then located near the mouth of the Gulf, became unstable. As a result, the plate edge jumped inland to the Gulf, by rifting the peninsula of Baja California obliquely away from the mainland. Magnetic anomalies off the tip of Baja California demonstrate that the present phase of recorded sea-floor spreading in the Gulf started approximately 3.5 Ma. (Larson et al., 1968; Lewis et al., 1975). Earlier, only a relatively shallow, perhaps largely nonoceanic seaway lay along the trend where the modern Gulf of California developed.
The nature of this proto-Gulf of California has been controversial. Its existence can be demonstrated by differences in the thickness and nature of the sediment column in parts of the mouth of the Gulf and by the geometry of the fit produced by closing up the Gulf created during this $3.5-\mathrm{m} . \mathrm{y}$. period of opening, both in the mouth and along the axis of the Gulf. It can also be demonstrated by seismic reflection profiles and surface geology of the adjacent region, both on the land and under the sea. The ultimate proof must, however, come from drilling to establish the age of the overlying sediments and basement. Site 473, drilled during Leg 63, has contributed to this effort with the discovery of 6 m.y. old crust west of Tres Marias Islands (Yeats, Haq, et al., 1981).

\section{Multidisciplinary Objectives}

A drilling transect at the mouth of the Gulf of California is designed to combine the interests of the IPOD/ JOIDES Passive Continental Margin, Ocean Crust, and Ocean Paleoenvironment Panels. The primary multidisciplinary scientific objectives are of two types. First, the regional objectives address the tectonics of western North America, as discussed earlier, and paleoceanography and tectonics of the northeastern Pacific Ocean. Second are the many problems related to the origin and youthful stage of evolution of an ocean and its rifted, passive continental margins.

The history of the south-flowing California Current is of special interest to the Ocean Paleoenvironment Panel. This current has apparently existed since the Cretaceous, but its intensity has varied significantly during the Neogene in response to climatic changes. Following stable conditions until the middle Miocene, there have been several periods when isotherms have been displaced and the California Current extended as far southward as the mouth of the Gulf, alternating with northward shifts of isotherms, flora, and fauna. Of particular interest in this region are the extreme southward incursions of subpolar assemblages during Pleistocene glacial stages, alternating with interglacial northward migration of temperate assemblages.

Because of its proximity to a large continental mass, the young oceanic crust in the Gulf of California is overlain by variable thicknesses of sediment, much of it sufficiently thick to permit spudding the drill of Glomar Challenger. Here, then, is a very nearly unique opportunity for examining the nature of very young, almost zero-age, oceanic crust. Here is also a rare opportunity to examine the early stages of the evolution of a rift-type or passive continental margin not yet so deeply buried under sediment as to be beyond our drilling capability. The tip of Baja California, with its granitic and preintrusive rocks, is such a young evolving margin. It displays the same pattern of horst and graben and listric faulting as, it is suggested, deeply underlies the thick sediments of older Atlantic-type continental margins. The transition from continental to oceanic crust in the Gulf lies only a few hundred meters below the sea floor and is young enough that it has not undergone the modification which occurs with massive subsidence and sedimentation in older continental margins. 
The drilling transect across the lower continental slope of the tip of Baja California was planned to test the accuracy of our picture of this transition and to provide information on the subsidence history, paleoenvironments, and physical and chemical processes active in the early phases of the young margin.

Drilling in the Guaymas Basin offers an excellent opportunity to examine the formation products when new crust is formed under conditions of high sedimentation rates, high organic productivity, and the very high heat flow associated with spreading axis processes. This type of environment, although virtually confined to this locality in the modern oceans, must be considered a typical phase of crustal generation in the youngest stages of ocean formation following continental rifting. Knowledge of the products of the very early physical and chemical diagenesis associated with the mixing of fluid, young sediments and intruding spreading-center magmas may indeed provide a model for comparison with ancient environments of similar genesis.

\section{REFERENCES}

Atwater, T., 1970. Implications of plate tectonics for the Cenozoic tectonic evolution of western North America. Geol. Soc. Am. Bull., 81:3513-3536.

Chase, C. G., Menard, H. W., Lason, R. L., Sharman, G. F., III, and Smith, S. M., 1970. History of sea-floor spreading west of Baja California. Geol. Soc. Am. Bull., 81:491-498.

Cochran, J. R., 1981. The Gulf of Aden: Structure and evolution of a young ocean basin and continental margin. J. Geophs. Res., $86:($ no. B1):263-187

Curray, J. R., 1980. The IPOD programme on passive continental margins. Phil. Trans. R. Soc. London, Ser. A, 294(no. 1409): $17-33$

Curray, J. R., Moore, D. G., Lawver, L. A., Emmel, F. J., Raitt, R. W., Henry, M., and Kieckhefer, R., 1979. Tectonics of the Andaman Sea and Burma. In Watkins, J., Montadert, L., and Dickerson, P. W. (Eds.), Geological and Geophysical Investigations of Continental Margins. Am. Assoc. Pet. Geol. Mem. 29: Tulsa (AAPG), 189-198.

Dewey, J. F., and Bird, J. M., 1970. Mountain belts and the new global tectonics. J. Geophys. Res., 75:2625-2647.

Falvey, D. A., 1974. The development of continental margins in plate tectonic theory. Aust. Pet. Explor. Assoc. J., 14:95-106.

Gastil, R. G., Allison, E. C., and Phillips, R. P., 1968. Geological evidence relating to the origin of the northern half of the Gulf of California. In Maldonado-Koerdell, M. (Ed.), Pan-American Symposium on the Upper Mantle: (Vol. 2). Group 2: Upper Mantle Petrology and Tectonics. International Upper Mantle Symposia No. 22B: Mexico (Instituto de Geofisica, U.N.A.M), 1-22.

Hamilton, W., 1961. Origin of the Gulf of California. Geol. Soc. Am. Bull., 72:1307-1318.

Jensky, W. A., III, 1974. Reconnaissance geology and geochronology of the Bahia de Banderas Area, Nayarit and Jalisco, Mexico [M.S. Thesis]. University of California, Santa Barbara.

Karig, D. E., and Jensky, W. A., III, 1972. The proto-Gulf of California. Earth Planet. Sci. Lett., 17:169-174.

Kovach, R. L., Allen, C. R., and Press, F., 1962. Geophysical investigation in the Colorado Delta region. J. Geophys. Res., 67: 2845-2871.

Larson, R. L., 1972. Bathymetry, magnetic anomalies, and plate tectonic anomalies, and plate tectonic history of the mouth of the Gulf of California. Geol. Soc. Am. Bull., 83:3345-3360.

Larson, R. L., Menard, H. W., and Smith, S. M., 1968. Gulf of California: A result of ocean-floor spreading and transform faulting. Science, 161:781-784.

Lawver, L. A., and Williams, D. L., 1979. Heat flow in the Central Gulf of California. J. Geophys. Res., 84:3465-3478.
Lewis, B. T. R., McClain, J., Snydsman, W. E., Lister, C. R. B., Holmes, M. L., and Heitman, C., 1975. Gulf of California IPOD site survey, final report. (Unpubl. ms.)

Lonsdale, P., and Lawver, L. A., 1980. Immature plate boundary zones studied with a submersible in the Gulf of California. Geol. Soc. Am. Bull., Pt. I, 91:555-569.

McKenzie, D. P., and Parker, R. L., 1967. The North Pacific: An example of tectonics on a sphere. Nature, 216:1276-1280.

Menard, H. W., 1960. The East Pacific Rise. Science, 132: $1737-1746$.

Montadert, L., Roberts, D. G., et al., 1979. Init. Repts. DSDP, 48: Washington (U.S. Govt. Printing Office).

Moore, D. G., 1973. Plate-edge deformation and crustal growth, Gulf of California structural province. Geol. Soc. Am. Bull., 84: 1883-1906.

Moore, D. G., and Buffington, E. C., 1968. Transform faulting and growth of the Gulf of California since the late Pliocene. Science, 161:1238-1242.

Moore, G. F., Becker, K., Bibee, L. D., Crane, K., Curray, J. R., Guerrero, J., Hawkins, J. W., Kastens, K., Kastner, M., Lawver, L. A., Melchior, J., Vacquier, V., and Williams, D. L., 1978. Gulf of California IPOD site summary, final report. (Unpubl. ms.)

Morgan, W. J., 1968. Rises, trenches, great faults, and crustal block. J. Geophys. Res., 73:1959-1982.

Normark, W. R., and Curray, J. R., 1968. Geology and structure of the tip of Baja California, Mexico. Geol. Soc. Am. Bull., 69: $1589-1600$.

Oldenberg, D. W., and Brune, J. N., 1975. An explanation for the orthogonality of ocean ridges and transform faults. J. Geophys. Res., 80:2575-2585.

Reichle, M. S., and Reid, I., 1977. Detailed study of earthquake swarms from the Gulf of California. Bull. Seismol. Soc. Am., 67: 159-171.

Reichle, M. S., Sharman, G. F., and Brune, J. N., 1976. Sonobuoy and teleseismic study of Gulf of California transform fault earthquake sequences. Bull. Seismol. Soc. Am., 66:1623-1641.

Rusnak, G. A., and Fisher, R. L., 1964. Structural history and evolution of Gulf of California. In van Andel, Tj. H., and Shor, G. G., Jr. (Eds.), Marine Geology of the Gulf of California: A Symposium: Am. Assoc. Pet. Geol. Mem. 3: Tulsa (AAPG), 144-156.

Rusnak, G. A., Fisher, R. L., and Shepard, F. P., 1964. Bathymetry and faults of the Gulf of California. In van Andel, Tj. H., and Shor, G. G., Jr. (Eds.), Marine Geology of the Gulf of California: A Symposium: Am. Assoc. Pet. Geol. Mem. 3: Tulsa (AAPG), 59-75.

Sharman, G. F., 1976. The plate tectonic evolution of the Gulf of California [Ph.D. dissert.]. University of California, San Diego, Scripps Institution of Oceanography.

Shephard, F. P., 1950. Submarine Topography of the Gulf of California: Pt. 3 of the 1940 E. W. Scripps Cruise to the Gulf of California. Geol. Soc. Am. Mem. 43.

Sibuet, J. C., Ryan, W. B. F., et al., 1979. Init. Repts. DSDP, 47, Washington (U.S. Govt. Printing Office).

Sykes, L. R., 1968. Seismological evidence for transform faults, seafloor spreading, and continental drift. In Phinney, R. A. (Ed.), The History of the Earth's Crust: A Symposium: Princeton (Princeton Univ. Press), pp. 120-150.

Vine, F. J., 1966. Spreading of the ocean floor-new evidence. Science, 154:1405-1415.

Watts, A. B., and Steckler, M. S. 1979. Subsidence and eustasy at the continental margin of eastern North America. In Talwani, M., Hay, W., and Ryan, W. B. F. (Eds.), Deep Sea Drilling Results in the Atlantic Ocean: Continental Margin and Paleoenvironment. Maurice Ewing Ser. 3: Washington (Am. Geophys. Union), 218-239.

Wegener, A., 1924. The Origin of Continents and Oceans, trans. by J. Biram: New York (Dover), 1966.

Williams, D. L., Becker, K., Lawver, L. A., and Von Herzen, R. P., 1979. Heat flow at the spreading centers of the Guaymas Basin, Gulf of California. J. Geophys. Res., 84:6757-6769.

Wilson, J. T., 1965. A new class of faults and their bearing on continental drift. Nature, 207:343-347.

Yeats, R. S., Haq, B. U., et al., 1981. Init. Repts. DSDP, 63: Washington (U.S. Govt. Printing Office). 